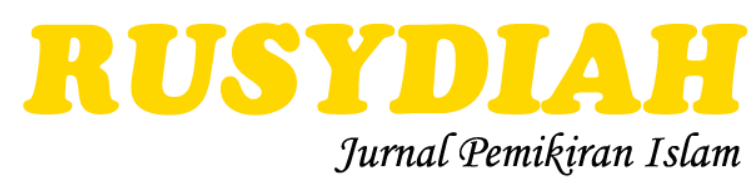

Volume 2 Nomor 2, Desember 2021

ISSN: 2723-4894 (cetak), ISSN: 2723-4886 (daring)

DOI: https://doi.org/10.35961/rsd.v2i2.352

\title{
RECONSTRUCTION OF BASIC CONCEPTS OF THE IMPLEMENTATION OF PROGRESSIVE ISLAM IN STUDENT ACTIVITIES
}

\author{
Teguh Luhuringbudi \\ Sekolah Pascasarjana UIN Syarif Hidayatullah Jakarta \\ sampaiteguh@gmail.com \\ Emah Rahmaniah \\ Universitas Muhammadiyah Prof. DR. HAMKA \\ emahrahmaniah26@gmail.com
}

Fitri Liza

Universitas Muhammadiyah Prof. DR. HAMKA

fitriliza@uhamka.ac.id

Dewi Nita Utami

Institut Agama Islam Negeri Jember

dewinitautami2@gmail.com

\begin{abstract}
Abstrak
Tulisan ini tidak hanya ditujukan pada ketidaksependapatan pada pandangan Dina Rafidiyah dan Fasho Tio Anugrah dan upaya pengembangan pemikiran mereka, tetapi juga menghadirkan formula konsep dasar penerapan Islam Berkemajuan yang sederhana dan mudah diterapkan dalam aktivitas mahasiswa di Perguruan Tinggi Muhammadiyah. Peneliti menggunakan pendekatan media melalui perspektif globalisasi yang diperkenalkan oleh Gill Branston dan Roy Stafford dalam menganalisa aktivitas mahasiswa di Perguruan Tinggi Muhammadiyah sebagai objek penelitian ini. Kesimpulan dari penelitian ini adalah pengadaan materi pemahaman mahasiswa terhadap konsep Islam Berkemajuan dan penerapan nilai-nilainya yang menekankan kreativitas dan inovasi melalui dasar Qurani dalam tingkah laku dan kehidupan budaya kampus. Penelitian ini juga menghasilkan temuan turunan yang berasal dari kesimpulan tersebut. Temuan pertama adalah perlunya materi pemahaman mahasiswa terhadap konsep Islam Berkemajuan yang menekankan kreativitas dan inovasi melalui dasar Qurani dalam tingkah laku seperti aspek kedewasaan akademik dalam bersosmed; dan aspek aksi sosial dalam kehidupan sehari-hari. Temuan kedua adalah penerapan nilai-nilai Islam Berkemajuan dalam kehidupan budaya kampus
\end{abstract}


melalui aspek pengawalan dan pengakhiran pembelajaran dengan kajian ayat-ayat Quran tematis; dan aspek penjaminan karir dan pembekalan skill-pengalaman bisnis.

Kata Kunci: Islam Berkemajuan; Aktivitas Mahasiswa; Perguruan Tinggi Muhammadiyah; Globalisasi.

\begin{abstract}
This paper is not only aimed at disagreements with the views of Dina Rafidiyah and Fasho Tio Anugrah and their efforts to develop their thoughts, but also presents a basic concept for the application of progressive Islam that is simple and easy to apply in student activities at Muhammadiyah Higher Education. Researchers used a media approach through a globalization perspective introduced by Gill Branston and Roy Stafford in analyzing student activity at Muhammadiyah Higher Education as the object of this study. The conclusion of this study is the provision of material for students' understanding of the concept of progressive Islam and the application of its values that emphasize creativity and innovation through the basis of the Quran in the behavior and cultural life of the campus. This paper also produces derivative findings that come from these conclusions. The first finding is the need for material for students' understanding of the concept of progressive Islam that emphasizes creativity and innovation through the Quranic basis in behavior such as aspect of academic maturity in social media; and aspect of social action in everyday life. The second finding is the application of Progressive Islamic values in the cultural life of the campus through the aspect of guarding and ending learning by studying thematic Quranic verses; and aspect of career assurance and business experience-skills provision
\end{abstract}

Keywords: Progressive Islam; Student Activities; Muhammadiyah Higher Education; Globalization.

\title{
INTRODUCTION
}

The implementation of progressive Islamic values is based on the Al-Quran and Sunnah. ${ }^{1}$ The application of Progressive Islamic (Islam Berkemajuan) values can provide learning understanding to students and female students to make it applicable in everyday life. Progressive Islam has a connection with the argument of QS. 3: 104. The purpose of this verse is to instruct Muslims to move in the field of da'wah and call for virtue so that later Islam will advance and become Rahmatan li al-Ālamin.

Progressive Islam can be understood with the thought of understanding Dinul Isläm (Islam) itself. Muhammadiyah has the view that Islam is a religion that stores the teaching values of development to carry out the main advancement of mankind. Muhammadiyah is responsible for continuing to advance the image and task of progressing Islam as the spirit of its early emergence. The role of Progressive Islam can be carried out if Muhammadiyah mobilizes participation

${ }^{1}$ Kurdie S. Model Perguruan Tinggi Agama Islam Berkemajuan. In: The 5th URECOL Proceeding. 2017. p. 979-88. 
from student activities to become a pioneer in the rise of Progressive Islam. The role of the community and/or society is very much needed to help Progressive Islam be conveyed well in the community.

An understanding of Progressive Islam is very good for students in developing personal abilities which can then be conveyed to the community properly and correctly. The Progressive Islamic applications for students that contain values and Rahmatan li al-'Álamin are very necessary so that they have guidelines in carrying out activities properly and correctly. The community has contributed to the smooth development of progressive Islam. In fact, every human being has a role in developing progressive Islam. In the 2019 Tanwir Muhammadiyah Enlightenment note in Bengkulu, part one of the clauses contains "beragama yang menerangkan kemajuan dalam penglihatan, perilaku dan pelaksanaan keagamaan yang berwatak tengahan (wasathiyah), menciptakan perdamaian, menghargai keberagaman, menghormati derajat dan kedudukan kemanusiaan laki-laki dan perempuan, menjunjung tinggi keadaban mulia, dan memajukan kehidupan umat manusia yang diwujudkan dalam sikap hidup amanah, adil, kebaikan, saling menghargai, kasih sayang terhadap umat manusia tanpa pemecahan dan menghormati keberagaman dan adat istiadat sosial yang utama sebagai aktualisasi nilai dan misi rahmatan lil-'alamin. "2

The view of globalization theory states that globalization is a feature that marks the modern era and this also shares the spirit of progressive Islamic values. 3 Globalization arises from activities that take place in the global arena and often includes technology that makes things faster to communicate. 4 The view of globalization in today's modern era is very important because in the current era it is the era of 4.0 which means that every activity carried out is all focused on technology that can be connected to the elimination of physical distance. This reason is based on the reason that the development of this technology is a necessity in the era of globalization. In QS. 3: 104, it can be explained that fellow Muslims

${ }^{2}$ Religion that explains progress in vision, behavior and practice of religion of a moderate character (wasathiyah), creates peace, respects diversity, respects the degree and position of humanity of men and women, upholds noble civilization, and advances human life which is manifested in an attitude of life, trustworthiness, fairness, kindness, mutual respect, compassion for human beings without division and respect for diversity and the main social customs as the actualization of the values and mission of rahmatan lil-'alamin.

3 Gill Branston and Roy Stafford. The Media Student's Book (London and New York: Routledge, 2003).

4 Gill Branston and Roy Stafford. The Media Student's Book. p. 404-405. 
must remind each other in goodness, for example, like preaching. Da'wah in the modern era today can be articulated as da'wah that can be done through social media by maintaining that the substance of the message conveyed can be listened to and understood by many people. Many people think that preaching and sermons are old methods which they think are boring until they finally ignore the messages contained therein, but the current era places the advancement of globalization technology as a means of preaching so that it can be conveyed through social media which almost everyone is more accustomed to and active in using it so that the ease of witnessing, understanding, and taking lessons is a must. The opinion of Gill Branston and Roy Stafford regarding the global arena, globalization technology, and elimination of physical distance becomes relevant if it is applied in understanding the 4.0 era with the object of student activities and the spirit of progressive Islamic values so that all activities carried out by humans can be monitored.

This paper opposes the views of Dina Rafidiyah and Fasho Tio Anugrah which depart from subjective reality which cannot be generalized in its application. The researcher is of the opinion that the paper written by Rafidiyah and Anugrah resulted in students' diverse understanding of the concept of Progressive Islam; two progressive implementations of Islamic values in campus life; and eight applications of Progressive Islamic values in personal life 5 are local wisdom that is factual and subjectively ideal in certain dimensions of space and time so that it requires further conceptual enrichment in order to perfect it. the concept of "ready-to-use" in various Muhammadiyah universities in an ideologicaldogmatic manner and in various non-Muhammadiyah universities in an articulative-acculturative-substantive-assimilative manner. The concept of "readyto-use" Progressive Islam which is more articulate-substantive-assimilativeacculturative that this researcher wants to express is an effort that does not only build an image of the universality of Islam or rahmatan li al-'Alamin alone, but strives for the presence of a generation that has Islamic awareness that strong as capital in social interactions that are "worldwide." Rafidiyah and Anugrah's research which contributes to bringing local phenomena to national level as an effort to globalize understanding also requires enrichment of epistemological and axiological foundations that will be conveyed by researchers as a refinement of the

${ }^{5}$ DinaRafidiyah and Fasha Tio Anugrah, "Implementasi Nilai-Nilai Islam Berkemajuan melalui Kegiatan Kemahasiswaan Perguruan Tinggi Muhammadiyah," Proceeding of The URECOL (2019), p. 236244. 
ideology of "Islam that blesses the world" and will later become a reconstructive concept for the benefit of the universe originating from The Qur'an, Hadith, and the ideal idea of the Muhammadiyah organization, namely "to present a true Islamic society." This view is the main reason and purpose of the researcher in this paper. The researcher views that Progressive Islamic values through Muhammadiyah university student activities need to be studied through a media approach with a globalization perspective promoted by Gill Branston and Roy Stafford to see a picture of typical ideological-normative-subjective-dogmatic activities that dream of positive change on a global scale.

\section{METHOD}

This research utilizes library research for collecting the data and analyzing with globalization perspective. ${ }^{6}$ Student activities with dogmatic-ideologicalnormative values such as Progressive Islam in the 4.0 era can be held transparently with a wide range of benefits through media such as Whatsapp, Facebook, Twitter, Instagram, TikTok, and Youtube. All of these applications are connected to the internet (a network that can connect electronic devices to one another) regardless of physical distance.7 This globalization perspective makes everyone, including students, easily receive and provide information that they want to convey globally.

The globalization perspective has a special factor that serves as a cultural strength, namely local reach that is built to become global success. ${ }^{8}$ The data collection procedure used in the context of this research is an inventory of various student activities on campus; and the data analysis procedure by interpreting the activities of associations (students) which are characterized by Islamic normativity to develop into global inspiration. Miller argues that the location of activities on a "global" scale often results in damage to the local environment 9 and ultimately the state must be responsible for financing the restoration of the situation. ${ }^{10}$ This view has become one of the considerations for the second data analysis procedure, namely interpreting and predicting student activities that do not conflict with the

\footnotetext{
${ }^{6}$ Gill Branston and Roy Stafford. The Media Student's Book, p. 139.

7 Mark Balnaves, Stephanie Hemelryk Donald, and Brian Shoesmith, Media Theories and Approaches: A Global Perspective (London and New York: Palgrave MacMillan, 2009), p. 5.

${ }^{8}$ Gill Branston and Roy Stafford. The Media Student's Book, p. 139.

${ }^{9}$ Miller, et.al, Global Hollywood (London: British Film Institute, 2001), p. 197.

10 Winarno B, 'Globalisasi dan rezim demokrasi poliarki: kebijakan integrasi ekonomi Indonesia', Jurnal Hubungan Internasional, 3.1(2014), p. 1-12.
} 
local environment, but contribute positively to the national interest sporadically. The second data analysis procedure was also carried out by submitting a review of the guidance of nobility that might exist in student activities such as the spirit of jargon and Islamic values promoted by Muhammadiyah. Branston and Stafford also emphasize that the merging of the terms "global" and "local" into "glocal" illustrates the capacity of modern consumer capitalism which tends to increase differences in line with prioritizing local culture. ${ }^{11}$ This view becomes the basis for the third data analysis procedure, namely recording and interpreting the possibility of public or global market attention on the locality of student activities. Marshall McLuhan emphasized the benefits experienced by a country from globalization by establishing intercultural relations to forming a global mass culture (global village). ${ }^{12}$ This view also formulates the fourth data analysis procedure which emphasizes the effort to analyze the benefits for a country that come from the global interaction of students.

The globalization perspective has a special factor that serves as a cultural strength, namely local reach that is built to become global success. ${ }^{13}$ The data collection procedure used in the context of this research is an inventory of various student activities on campus; and the data analysis procedure by interpreting the activities of associations (students) which are characterized by Islamic normativity to develop into global inspiration. Miller argues that the location of activities on a "global" scale often results in damage to the local environment ${ }^{14}$ and ultimately the state must be responsible for financing the restoration of the situation.15 This view has become one of the considerations for the second data analysis procedure, namely interpreting and predicting student activities that do not conflict with the local environment, but contribute positively to the national interest sporadically. The second data analysis procedure was also carried out by submitting a review of the guidance of nobility that might exist in student activities such as the spirit of jargon and Islamic values promoted by Muhammadiyah. Branston and Stafford also emphasize that the merging of the terms "global" and "local" into "glocal" illustrates the capacity of modern consumer capitalism which tends to increase

${ }^{11}$ Gill Branston and Roy Stafford. The Media Student's Book, p. 149.

12 Marshall McLuhan, The Gutenberg Galaxy (Toronto: University of Toronto, 1963).

${ }^{13}$ Gill Branston and Roy Stafford. The Media Student's Book, p. 149.

${ }^{14}$ Miller, et.al, Global Hollywood, p. 197.

15 Winarno, B. 'Globalisasi dan rezim demokrasi poliarki: kebijakan integrasi ekonomi Indonesia', p. $1-12$. 
differences in line with prioritizing local culture. ${ }^{16}$ This view becomes the basis for the third data analysis procedure, namely recording and interpreting the possibility of public or global market attention on the locality of student activities. Marshall McLuhan emphasized the benefits experienced by a country from globalization by establishing intercultural relations to forming a global mass culture (global village). ${ }^{17}$ This view also formulates the fourth data analysis procedure which emphasizes the effort to analyze the benefits for a country that come from the global interaction of students.

Globalization will continue to develop in line with the times and make the media as a global entity. This research relates to the context of globalization because of the speed of the flow of communication and information in all parts of the world, one of the subjects is students. Media globalization has unwittingly had the opposite trend. ${ }^{18}$ This view can be understood that the globalization of the media does not always present controversies and negativity that damage the younger generation, but instead has an impact on the spread of wisdom of local goodness values in front of world audiences and viewers. Changes that occur due to the rapid impact of globalization do not necessarily eliminate conflict and inequality, even the media can play a role in "covering" various gaps, conflicts, and horizontal human unconsciousness. ${ }^{19}$ This opinion is in line with the context of this research which emphasizes the nuances of globalization and the value of Progressive Islam, one of which is the younger generation such as students who allow their activities to be recorded in the media and presented as productive and constructive information for the global community

\section{RESULT AND DISCUSSION}

\section{Material for Students' Understanding of Progressive Islamic Concepts}

Creativity and innovation are the basis of the Quran in applying the concept of progressive Islam. Theorem of QS. 28:77 is an important key to human life that deserves to be used as a basis for the existence of the jargon and the concept of Progressive Islam which emphasizes the effort to create a new mystical atmosphere with a visionary to eschatological orientation in the world and the

\footnotetext{
${ }^{16}$ Gill Branston and Roy Stafford. The Media Student's Book, p. 149.

${ }^{17}$ Marshall McLuhan, The Gutenberg Galaxy.

${ }^{18}$ Gill Branston and Roy Stafford. The Media Student's Book, p. 154.

${ }^{19}$ Ibid, p. 160.
} 
hereafter. Students with the nicknames of agents of change or agents of social control are not only hopes of QS 28:77 which must always create innovative ideas for a productive psychic atmosphere that is only long-term oriented, but also real action as a form of creativity in order to present a balance of maturity between ideals and reality. Academic maturity of students is a vital aspect whose indicators must be determined as the views of Siobhan Lynam and Moira Cachia which state that "academic maturity" in articulating material so as to minimize stresses and encouragement of participation in the public arises from personal qualities and emotional factors. ${ }^{20}$ Miller's view regarding the location of "global" scale activities such as social media and the responsibility for recovery is a reference that students who live the concept of progressive Islam must be responsible for their academic maturity. This demand can be seen from the level of success of the level of student follow-up to the delivery of lecture material on their various social media accounts; how sincere the student's actions have been in delivering lecture material simply and substantially to the family for the purpose of da'wah; application of worldly nuanced social ideas for the benefit of netizens originating from certain lecture materials; creating innovations in the act of sharing videos and social images on Instagram and Youtube related to the phenomena of natural disasters and social imbalances; how the intensity of reading and downloading lecture materials in foreign languages is self-taught.

\begin{tabular}{|c|c|c|c|c|c|c|c|c|c|c|}
\hline \multirow[t]{2}{*}{ No } & \multirow[t]{2}{*}{ Aspect } & \multirow[t]{2}{*}{ Indicator } & \multirow{2}{*}{$\begin{array}{c}\text { Divine } \\
\text { Source - } \\
\text { Reference } \\
\end{array}$} & \multicolumn{5}{|c|}{ Amount } & \multirow[t]{2}{*}{ Total } & \multirow[t]{2}{*}{ Average } \\
\hline & & & & 1 & 2 & 3 & 4 & 5 & & \\
\hline 1 & $\begin{array}{l}\text { Academic } \\
\text { Maturity } \\
\text { in social } \\
\text { media }\end{array}$ & $\begin{array}{l}\text { The extent to } \\
\text { which } \\
\text { students } \\
\text { follow up on } \\
\text { the delivery of } \\
\text { lecture } \\
\text { material on } \\
\text { their various } \\
\text { social media } \\
\text { accounts }\end{array}$ & QS. 28:77 & & & & & & & \\
\hline & & $\begin{array}{l}\text { The level of } \\
\text { sincerity of the } \\
\text { student's } \\
\text { actions that } \\
\text { have been } \\
\text { carried out in }\end{array}$ & & & & & & & & \\
\hline
\end{tabular}

20 Siobhan Lynam and Moira Cachia, 'Students' perceptions of the role of assessments at higher education', Assessment E Evaluation in Higher Education, 43.2 (2018), p. 223-234. 


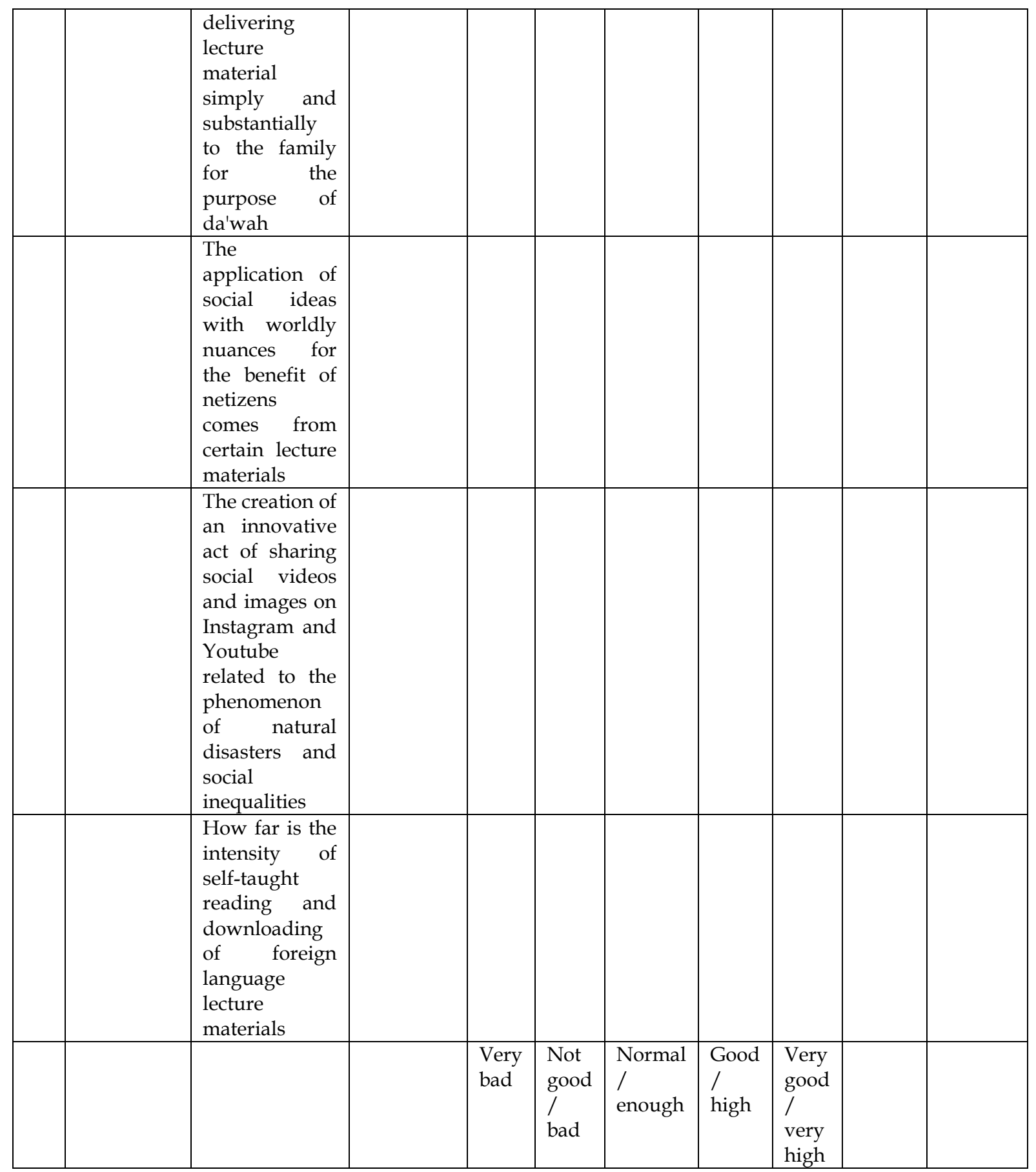

The imitation and application of the teachings of the Koran through social action in everyday life not only reflects the Living Quran and the embodiment of Progressive Islam which demands the presence of a "true Islamic society" (masyarakat Islam yang sebenar-benarnya), but also a local long-term development platform for global success in Branston and Stafford's thinking. Rafidiyah and Tio 
Anugrah who stated that the manifestation of Progressive Islam by students in competition in all fields with the international community ${ }^{21}$ needs to be articulated into real technical actions as the thematic-synchronic exemplary QS. 2: 185, productive and constructive role models and public figures QS. 33:21, and the guidelines for success for human choice QS. 2: 2-6. Social action based on certain verses of the Koran needs to become a mandatory requirement of higher education policies for all students based on their interests, desires and needs ${ }^{22}$ by preparing assessment instruments stipulated in the form of policies of the top leaders of higher education so that the quality of social interactions with an emphasis on their real actions ${ }^{23}$ able to bring a global mass ${ }^{24}$ culture with a global success mission without prioritizing sectoral egos. ${ }^{25}$ Policies on social action obligations based on certain Qur'anic verses and the existence of interests, desires and needs of individual students from higher education institutions also need to be arranged in the form of practical indicators so that the objectives can be achieved such as how to implement compulsory social action for students based on certain Qur'anic verses that are required by the higher education's policy; how to mentor and monitor student social actions based on certain verses of the Koran by employees in the tertiary institution; the extent to which the accuracy of the target community targeted by students from their social actions; and how is the student's social action evaluation mechanism. This policy is in line with the ISMUBA (al-Islām, Kemuhammadiyahan, and Arabic) curriculum which emphasizes the function of education for intelligence, community service, da'wah, and regeneration, ${ }^{26}$ preparation of the best generation, Khairu al-Ummah. ${ }^{27}$

\begin{tabular}{|c|c|c|c|c|c|c|c|c|c|c|}
\hline \multirow{2}{*}{ No } & \multirow{2}{*}{ Aspect } & \multirow{2}{*}{ Indicator } & \multirow{2}{*}{$\begin{array}{c}\text { Divine } \\
\text { Source - } \\
\text { Reference }\end{array}$} & \multicolumn{5}{|c|}{ Amount } & \multirow[t]{2}{*}{ Total } & \multirow[t]{2}{*}{ Average } \\
\hline & & & & 1 & 2 & 3 & 4 & 5 & & \\
\hline 1 & Imitation & The & QS. 2:185, & & & & & & & \\
\hline
\end{tabular}

21 Dina Rafidiyah dan Fasha Tio Anugrah, 'Implementasi Nilai-nilai Islam Berkemajuan....', Proceeding of the URECOL: The $10^{\text {th }}$ University Research Colloqium (2019), pp. 236-244.

${ }^{22}$ S. Z. Bin-Tahir, et.al, 'The Social Media Use for Digital Natives: Parenting Model of Muslim Cleric Families', International Jornal of Scientific \& Technology Research, 8.11 (2019), pp. 2871-2874.

23 Esmail Salem Khoei, Seyyed Taghi Kabiri, and Mahboob Mahdavian, 'Studying Effective Educational Strategies in Reducing Extremist Phenomena in Quran and Holy Books', MIER Journal of Educational Studies Trends and Practices, (2020): pp. 138-145.

${ }^{24}$ Marshall McLuhan, The Gutenberg Galaxy.

${ }^{25}$ Gill Branston and Roy Stafford. The Media Student's Book. p. 149.

26 Zalik Nuryana, 'Revitalisasi Pendidikan Al-Islam Dan Kemuhammadiyahan Pada Perguruan Muhammadiyah', Tamaddun: Jurnal Pendidikan Dan Pemikiran Keagamaan, 18. 1 (2017): pp. 1-11.

27 Zalik Nuryana, et.al, 'Literation Movement for Leading Schools: Best Practice and Leadership Power', International Journal of Evaluation and Research in Education, 9.1 (2020): pp. 227-233. 


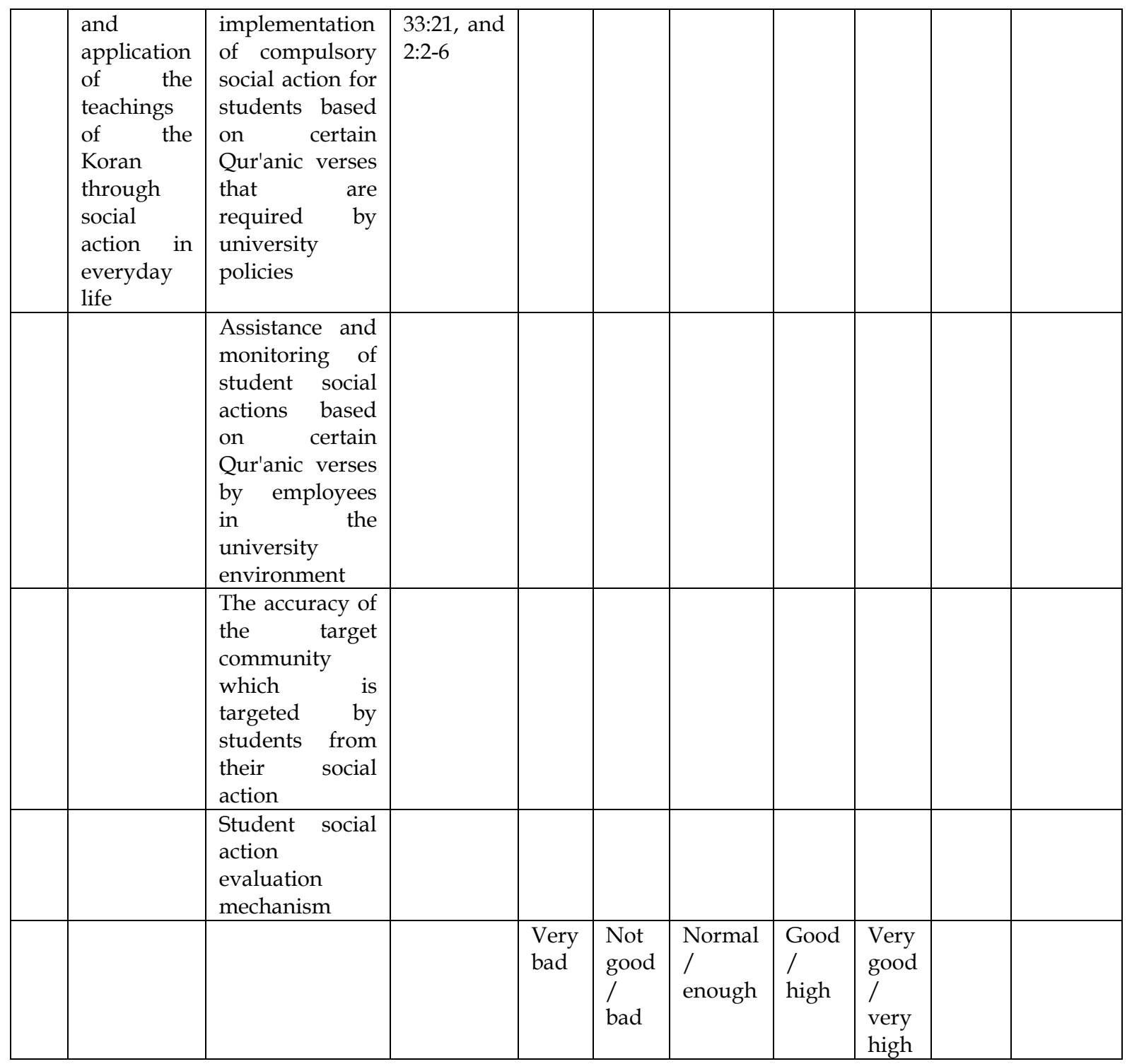

\section{Progressive Islamic Values in Campus/University Cultural Life}

Lecture learning that begins with the recitation of certain verses of the Koran is one of the subjective-dogmatic obligations that must be used as the first aspect of implementing the value of Progressive Islam in university or campus cultural life while still upholding the nuances of globalization. The reading of certain verses in the Koran before and after learning with short duration ${ }^{28}$ in class

${ }^{28}$ Syafrimen Syafril dan Nova Erlina Yaumas, 'The implementation of Tartil Method in improving elementary school students' ability in reading al-Qur'an', Khalifa Journal of Islamic Educational, 1. 1 (2017): p. 1-14. 
not only reflects Islamic values, ${ }^{29}$ but also trains the ability to concentrate and memorize verses from the Qur'an collectively.30 The joint reading led by the lecturer also means nothing if it is not accompanied by a simple delivery of the Qur'anic interpretations which are referenced from the original book which uses Arabic in the form of a PDF file. This design also requires not only time restrictions such as 10 minutes before and after learning which results in learning time for certain courses to be 80 minutes, but efforts to enrich the treasures of scientific integration and enrichment of foreign languages in any subject so that it becomes a reflection of lecturers' readiness to interact with global literacy. Lecturers who teach any subject need to prepare a certain verse of the Qur'an at each lecture meeting and be familiar with global interactions through an intermediate understanding of Arabic script. This subjective doctrine needs to be made into a habit ${ }^{31}$ so that the nuances of Progressing Islam based on thematic verses of the Koran are not only included in various integrated subjects, ${ }^{32}$ but also the creation of stimulation of bilingual nuances in the classroom ${ }^{33}$ as Branston and Stafford's globalization views regarding global success related to international language interactions ${ }^{34}$ and efforts to improve teachers or lecturers' resources as fundamental capital in the realm of educationn. ${ }^{35}$ The reading of the original text of the Koran interpretation using Arabic can also be understood as the dominance of the language contained in it in communication, 36 but also the combination of local

${ }^{29}$ A. Alhamuddin, et.al, 'Developing Al-Quran Instruction Model Through 3 A (Ajari Aku Al-Quran Or Please Teach Me Al-Quran) to Improve Students'ability in Reading Al-Quran at Bandung Islamic University', International Journal of Education, 10. 2 (2018): p. 95-100.

${ }^{30}$ Abdul Halik, Zulfianah, and Muh Naim, 'Strategies of Islamic Education Teachers to Increase Students' Interest In Learning and Practicing in State Junior High School Lanrisang (SMPN) 1 Lanrisang, Pinrang', MADANIA: Jurnal Kajian Keislaman, 22. 2 (2018): p. 253-264.

${ }^{31}$ Tedi Supriyadi dan J. Julia, 'The Problem of Students in Reading the Quran: A Reflective-Critical Treatment through Action Research', International Journal of Instruction, 12. 1 (2019): p. 311-326. S. W. Hanafie Das, et.al, 'Strategies of Islamic Education Teachers to Increase Students' Interest in Learning and Practicing in State Junior High School (SMPN) 1 Lanrisang, Pinrang,' MADANIA, 22.2 (2018): p. $253-264$.

${ }^{32}$ Ulfatul Husna dan Muhammad Thohir, 'Religious Moderation as a New Approach to Learning Islamic Religious Education in Schools'," Nadwa: Jurnal Pendidikan Islam, 14. 1 (2020), p. 199-222.

33 N. Haffar, et.al, 'Pedagogical indexed arabic text in Cloud E-learning system', International Journal of Cloud Applications and Computing (IJCAC), 7 (2017), p. 32-46.; Saidna Zulfiqar Bin Tahir, 'Multilingual teaching and learning at Pesantren Schools in Indonesia', Asian EFL Journal, 89 (2017) p. 7494.

${ }^{34}$ Gill Branston and Roy Stafford. The Media Student's Book, p. 149.

35 Siti Noor Azizah, Suparwoto, and Zalik Nuryana, 'An evaluation toward the post-certification teacher performance in the natural history learning process for the elementary school degree', Psychology, Evaluation, and Technology in Educational Research, 2, 2 (2020), p. 115-128.

${ }^{36}$ M. Jannah, \& A. A. Nababan, 'Harfu Jar Detection System In Al-Quran Using Pierce Similarity Algorithm as a Basic Learning Media of Arabic Language', In 2020 3rd International Conference on Mechanical, Electronics, Computer, and Industrial Technology (MECnIT) (2020), pp. 349-354.

Rusydiah: Jurnal Pemikiran Islam, Vol. 2, No. 2, Desember 2021 http://ejournal.stainkepri.ac.id/index.php/rusydiah 
interactions with global languages that are recognized by the United States (US) into a "glocal" atmosphere in the perspective of globalization in the scientific clumps of the media being carried by Branston and Stafford. 37

\begin{tabular}{|c|c|c|c|c|c|c|c|c|c|c|}
\hline \multirow[t]{2}{*}{ No } & \multirow[t]{2}{*}{ Aspect } & \multirow[t]{2}{*}{ Indicator } & \multirow{2}{*}{$\begin{array}{c}\text { Divine } \\
\text { Source - } \\
\text { Reference }\end{array}$} & \multicolumn{5}{|c|}{ Amount } & \multirow[t]{2}{*}{ Total } & \multirow[t]{2}{*}{ Average } \\
\hline & & & & 1 & 2 & 3 & 4 & 5 & & \\
\hline \multirow[t]{6}{*}{1} & $\begin{array}{l}\text { Read the } \\
\text { Qur'anic } \\
\text { Verses for } \\
10 \\
\text { Minutes } \\
\text { Before } \\
\text { Starting } \\
\text { Learning }\end{array}$ & $\begin{array}{l}\text { Lecturers and } \\
\text { students read } 1 \\
\text { verse of the } \\
\text { Koran over and } \\
\text { over in a lecture }\end{array}$ & $\begin{array}{l}\text { QS. 29:45, } \\
\text { 33:34, } \\
35: 29 \text {, dan } \\
87: 6\end{array}$ & & & & & & & \\
\hline & & $\begin{array}{l}\text { Class members } \\
\text { recite the } \\
\text { meaning of the } \\
\text { thematic verses } \\
\text { of the Koran }\end{array}$ & & & & & & & & \\
\hline & & $\begin{array}{l}\text { Class members } \\
\text { read } \\
\text { interpretations } \\
\text { of thematic } \\
\text { verses of the } \\
\text { Koran in Arabic }\end{array}$ & & & & & & & & \\
\hline & & $\begin{array}{l}\text { The lecturer } \\
\text { provides a pdf } \\
\text { file and shows } \\
\text { the pages } \\
\text { related to the } \\
\text { interpretation } \\
\text { of the thematic } \\
\text { verse that is } \\
\text { being studied }\end{array}$ & & & & & & & & \\
\hline & & $\begin{array}{l}\text { The lecturer } \\
\text { delivers a } \\
\text { simple } \\
\text { interpretation } \\
\text { of the thematic } \\
\text { verses of the } \\
\text { Koran in } \\
\text { Indonesian }\end{array}$ & & & & & & & & \\
\hline & & & & $\begin{array}{l}\text { Very } \\
\text { bad }\end{array}$ & $\begin{array}{l}\text { Not } \\
\text { good } \\
/ \\
\text { bad }\end{array}$ & $\begin{array}{l}\text { Normal } \\
\text { / } \\
\text { enough }\end{array}$ & $\begin{array}{l}\text { Good } \\
/ \\
\text { high }\end{array}$ & $\begin{array}{l}\text { Very } \\
\text { good } \\
\text { / } \\
\text { very } \\
\text { high }\end{array}$ & & \\
\hline
\end{tabular}

${ }^{37}$ Gill Branston and Roy Stafford. The Media Student's Book, p. 149. 
Career guarantees and provision of business skills for students by the structural leadership of higher education are breakthroughs in articulating progressive Islam by involving a media approach through a globalization perspective. This idea is not only based on the urge to emulate the profession of the Prophet Muhammad SAW 38 and the preparation of a generation who deals in the business field based on innovations that answer market needs 39 in realizing business career dreams for students, 40 but also efforts to translate thumma razaqakum diction in QS. 30:40 practically and diction illā 'alallāhi rizquhā wa ya' lamu mustaqarrahā wa mustauda'ahā kullun fi kitābin mubinin in QS. 11: 6 technically. Providing work and business skills for students from an early age according to their study program, interests, and talents by higher education leaders to ensure the usefulness of their knowledge and experience after graduation is a practical explanation of the enlightenment movement in the second point of the Risalah Pencerahanan Hasil Tanwir Muhammadiyah Bengkulu 2019 as a form of support and participation in capitalist globalization against all forms of threats such as inequality, poverty, human unconsciousness and ignorance horizontally in Branston and Stafford's thinking. ${ }^{41}$ Provision of professional and business skills for students aimed at welcoming Indonesia's demographic bonus ${ }^{42}$ which can be understood as an effort to reduce the global poverty 43 rate is not only able to absorb the spirit of Progressive Islamic values with the ideological jargon of Rahmatan li al-'Alamīn and participating in global developments through the partnership mechanism of Muhammadiyah universities with other countries only,

${ }^{38}$ Haris Herman, 'Mengembangkan Minat Menjadi Wirausaha Mahasiswa dengan Metode Problem Based Learning (PBL): Studi Kasus Pada Mahasiswa FE Universitas Muhammadiyah Jember', In Prosiding Seminar Nasional \& Call For Paper (2016).

${ }^{39}$ Ambarwati and Indra Sumarna Sobari, 'Membangun Jiwa Kewirausahaan Di Era Milenial Bagi Mahasiswa Institut Stiami Kampus Tangerang Selatan', Jurnal Komunitas: Jurnal Pengabdian Kepada Masyarakat, 2.2 (2020), p. 140-144.

40 Tanti Prita Hapsari, 'Peran Lingkungan Kampus Dalam Memoderasi Pengaruh Mata Kuliah Kewirausahaan Terhadap Minat Wirausaha', Jurnal Ekonomi Pendidikan Dan Kewirausahaan, 6, 2 (2018), p. 197-214.

${ }^{41}$ Gill Branston and Roy Stafford. The Media Student's Book, p. 160.

${ }^{42}$ M. Subandowo, 'Peradaban dan Produktivitas dalam Perspektif Bonus Demografi serta Generasi Y dan Z', Sosiohumanika, 10. 2 (2017), p. 191-208.; Sita Dewi, Dwi Listyowati, and Bertha Elvy Napitupulu, 'Bonus Demografi Di Indonesia: Suatu Anugerah Atau Petaka', Journal Of Information System, Applied, Management, Accounting And Research, 2.3 (2018), p. 17-23.

43 Jason Gickel, 'The true extent of global poverty and hunger: questioning the good news narrative of the Millennium Development Goals', Third World Quarterly, 3.5 (2016), p. 749-767. Augustin Kwasi Fosu, 'Growth, inequality, and poverty reduction in developing countries: Recent global evidence', Research in Economics, 71. 2 (2017), p. 306-336. Lucy Page dan Rohini Pande, 'Ending global poverty: Why money isn't enough', Journal of Economic Perspectives, 32.4 (2018), p. 173-200. 
but also participate in advancing world welfare. 44 This fact needs to be formulated in indicators such as the extent to which periodic professional training is organized according to study programs for students every year; how the attention of universities in conducting business training for students every semester; how the university partnership efforts in the industrial sector so that companies come to recruit prospective graduates; the extent to which efforts to establish partnerships with various educational institutions and companies abroad to recruit students to become advanced level students (masters or doctorates) as well as professional workers; and the extent of employment and student unemployment rates after graduating from college or higher education.

\begin{tabular}{|c|c|c|c|c|c|c|c|c|c|c|}
\hline \multirow[b]{2}{*}{ No } & \multirow[b]{2}{*}{ Aspect } & \multirow[b]{2}{*}{ Indicator } & \multirow{2}{*}{$\begin{array}{c}\text { Divine } \\
\text { Source - } \\
\text { Reference } \\
\end{array}$} & \multicolumn{5}{|c|}{ Amount } & \multirow[b]{2}{*}{ Total } & \multirow[b]{2}{*}{ Average } \\
\hline & & & & 1 & 2 & 3 & 4 & 5 & & \\
\hline \multirow[t]{4}{*}{1} & \multirow{4}{*}{$\begin{array}{l}\text { Career } \\
\text { guarantees } \\
\text { and } \\
\text { provision } \\
\text { of } \\
\text { business- } \\
\text { experience } \\
\text { skills for } \\
\text { students by } \\
\text { the } \\
\text { university's } \\
\text { structural } \\
\text { leadership }\end{array}$} & $\begin{array}{l}\text { Organizing } \\
\text { periodic } \\
\text { professional } \\
\text { training } \\
\text { according to } \\
\text { the study } \\
\text { program for } \\
\text { students every } \\
\text { year }\end{array}$ & \multirow{4}{*}{$\begin{array}{c}\text { QS. 30:40 } \\
\text { dan QS. } \\
11: 6\end{array}$} & & & & & & & \\
\hline & & $\begin{array}{l}\text { The } \\
\text { university's } \\
\text { attention is in } \\
\text { providing } \\
\text { business } \\
\text { training for } \\
\text { students every } \\
\text { semester }\end{array}$ & & & & & & & & \\
\hline & & $\begin{array}{l}\text { Higher } \\
\text { education } \\
\text { partnership } \\
\text { efforts in the } \\
\text { industrial } \\
\text { sector so that } \\
\text { companies } \\
\text { come to recruit } \\
\text { prospective } \\
\text { graduates }\end{array}$ & & & & & & & & \\
\hline & & $\begin{array}{l}\text { Efforts to } \\
\text { establish } \\
\text { partnerships } \\
\text { with various }\end{array}$ & & & & & & & & \\
\hline
\end{tabular}

${ }^{44}$ Kerem Gabriel Öktem, 'The welfare state as universal social security: A global analysis', Social Inclusion, 8. 1 (2020), p. 103-113. Yungho Weng, Kuang-Chung Hsu, and Bih Jane Liu, 'Increasing worldwide environmental consciousness and environmental policy adjustment', The Quarterly Review of Economics and Finance, 71 (2019), p. 205-210. 


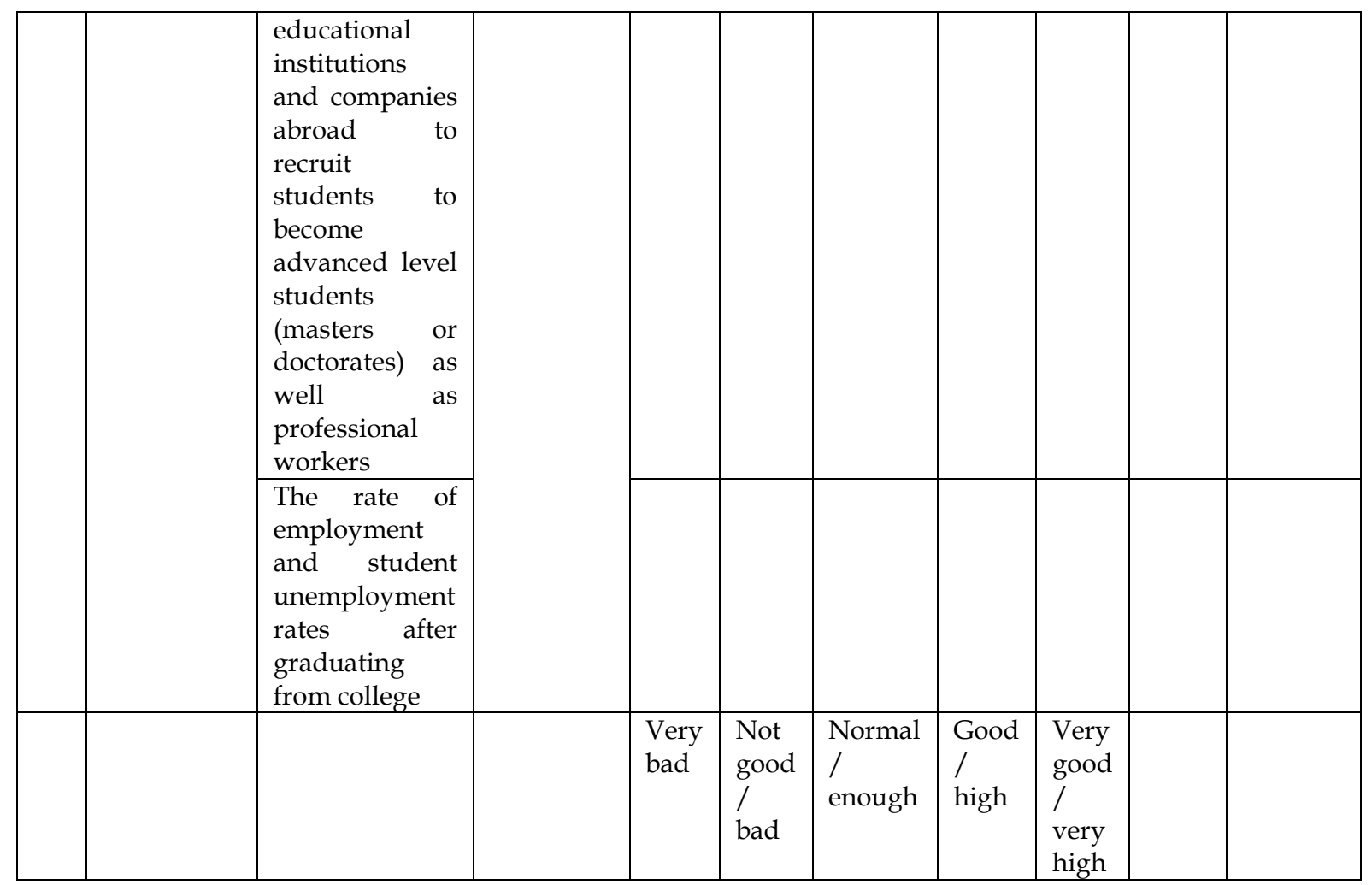

\section{CONCLUSION}

The research which aims to formulate the basic concepts of the application of Progressive Islam in student activities at Muhammadiyah Higher Education produces theoretical and practical conclusions that need attention. The conclusion of this research is the provision of material for students' understanding of the concept of progressive Islam and the application of its values that promote creativity and innovation based on the Qur'an in the behavior and cultural life of a Muhammadiyah campus or college. This paper also produces derivative findings derived from these conclusions. The first finding is the need for material understanding the concept of progressive Islam for students that emphasizes creativity and innovation through the al-Qur'an foundation in behaving like aspects of academic maturity on social media; and aspects of social action in everyday life. The second finding is the application of Progressive Islamic values in campus cultural life through aspects of guarding and ending learning by studying thematic Qur'anic verses; and aspects of career assurance and provision of business-skills experience. The researcher suggests and recommends further research that focuses on the effectiveness of student activities that contribute to the executive and legislative governments; further research that focuses on reporting on student activities that apply the nuances of Progressive Islam by foreign media; 
and further research that focuses on students' personal experiences in international Islamic activities.

\section{REFERENCES}

Alhamuddin, A., Hamdani, F., Tandika, D., \& Adwiyah, R. (2018). Developing AlQuran Instruction Model Through 3A (Ajari Aku Al-Quran Or Please Teach Me Al-Quran) to Improve Students'ability in Reading Al-Quran at Bandung Islamic University. International Journal of Education, 10(2), 95-100.

Ambarwati, A., \& Sobari, I. S. (2020). Membangun Jiwa Kewirausahaan Di Era Milenial Bagi Mahasiswa Institut Stiami Kampus Tangerang Selatan. Jurnal Komunitas: Jurnal Pengabdian Kepada Masyarakat, 2(2), 140-144.

Azizah, S. N., Suparwoto, S., \& Nuryana, Z. (2020). An evaluation toward the postcertification teacher performance in the natural history learning process for the elementary school degree. Psychology, Evaluation, and Technology in Educational Research, 2(2), 115-128.

Balnaves, Mark, Donald, Stephanie Hemelryk, and Shoesmith, Brian (2009) Media Theories and Approaches: A Global Perspective, London and New York: Palgrave MacMillan.

Bin Tahir, S. Z. (2017). Multilingual teaching and learning at Pesantren Schools in Indonesia. Asian EFL Journal, 89, 74-94.

Branston, Gill and Roy Stafford (2003). The Media Student's Book. London and New York: Routledge.

Dewi, S., Listyowati, D., \& Napitupulu, B. E. (2018). Bonus Demografi Di Indonesia: Suatu Anugerah Atau Petaka. Journal Of Information System, Applied, Management, Accounting And Research, 2(3), 17-23.

Dina Rafidiyah dan Fasha Tio Anugrah, "Implementasi Nilai-nilai Islam Berkemajuan melalui Kegiatan Kemahasiswaan Perguruan Tinggi Muhammadiyah," Proceeding of the URECOL: The 10 $0^{\text {th }}$ University Research Colloqium (2019): 236-244.

Fosu, A. K. (2017). Growth, inequality, and poverty reduction in developing countries: Recent global evidence. Research in Economics, 71(2), 306-336.

Haffar, N., Maraoui, M., Aljawarneh, S., Bouhorma, M., Alnuaimi, A. A., \& Hawashin, B. (2017). Pedagogical indexed arabic text in Cloud E-learning system. International Journal of Cloud Applications and Computing (IJCAC), 7(1), 32-46.

Halik, A., Zulfianah, Z., \& Naim, M. (2018). Strategies of Islamic Education Teachers to Increase Students' Interest In Learning and Practicing in State Junior High School Lanrisang (SMPN) 1 Lanrisang, Pinrang. MADANIA: Jurnal Kajian Keislaman, 22(2), 253-264. 
Hanafie Das, S. W., Halik, A., Zulfianah, Z., \& Naim, M. (2018). Strategies of Islamic Education Teachers to Increase Students' Interest in Learning and Practicing in State Junior High School (SMPN) 1 Lanrisang, Pinrang. MADANIA, 22(2), 253-264.

Hapsari, T. P. (2018). Peran Lingkungan Kampus Dalam Memoderasi Pengaruh Mata Kuliah Kewirausahaan Terhadap Minat Wirausaha. Jurnal Ekonomi Pendidikan Dan Kewirausahaan, 6(2), 197-214.

Hermawan, H. (2016, October). Mengembangkan Minat Menjadi Wirausaha Mahasiswa dengan Metode Problem Based Learning (PBL)(Studi Kasus Pada Mahasiswa FE Universitas Muhammadiyah Jember). In Prosiding Seminar Nasional \& Call For Paper.

Hickel, J. (2016). The true extent of global poverty and hunger: questioning the good news narrative of the Millennium Development Goals. Third World Quarterly, 37(5), 749-767.

Husna, U., \& Thohir, M. (2020). Religious Moderation as a New Approach to Learning Islamic Religious Education in Schools. Nadwa: Jurnal Pendidikan Islam, 14(1), 199-222.

Jannah, M., \& Nababan, A. A. (2020, June). Harfu Jar Detection System In Al-Quran Using Pierce Similarity Algorithm as a Basic Learning Media of Arabic Language. In 2020 3rd International Conference on Mechanical, Electronics, Computer, and Industrial Technology (MECnIT) (pp. 349-354). IEEE.

Khoei, E. S., Kabiri, S. T., \& Mahdavian, M. (2020). Studying Effective Educational Strategies in Reducing Extremist Phenomena in Quran and Holy Books. MIER Journal of Educational Studies Trends and Practices, 138-145.

Kurdie S. Model perguruan tinggi agama Islam berkemajuan. In: The 5th URECOL Proceeding. 2017. p. 979-88.

Lynam, Siobhan; Cachia, Moira. Students' perceptions of the role of assessments at higher education. Assessment \& Evaluation in Higher Education, 2018, 43.2: 223-234.

McLuhan, M. (1963). The Gutenberg Galaxy. Toronto: University of Toronto.

Miller, Toby, Govil, Nitin, McMurtia, John dan Maxwell, dan Richard, Global Hollywood (London: British Film Institute, 2001)

Nuryana, Z. (2017). Revitalisasi Pendidikan Al-Islam Dan Kemuhammadiyahan Pada Perguruan Muhammadiyah. Tamaddun: Jurnal Pendidikan Dan Pemikiran Keagamaan, 18(1), 1-11.

Nuryana, Z., Suroyo, A., Nurcahyati, I., Setiawan, F., \& Rahman, A. (2020). Literation Movement for Leading Schools: Best Practice and Leadership Power. International Journal of Evaluation and Research in Education, 9(1), 227233.

Öktem, K. G. (2020). The welfare state as universal social security: A global analysis. Social Inclusion, 8(1), 103-113. 
Page, L., \& Pande, R. (2018). Ending global poverty: Why money isn't enough. Journal of Economic Perspectives, 32(4), 173-200.

Rafidiyah, D., \& Anugrah, F. T. (2019). Implementasi Nilai-Nilai Islam Berkemajuan melalui Kegiatan Kemahasiswaan Perguruan Tinggi Muhammadiyah. Proceeding of The URECOL, 236-244.

Subandowo, M. (2017). Peradaban dan Produktivitas dalam Perspektif Bonus Demografi serta Generasi Y dan Z. SOSIOHUMANIKA, 10(2), 191-208.

Supriyadi, T., \& Julia, J. (2019). The Problem of Students in Reading the Quran: A Reflective-Critical Treatment through Action Research. International Journal of Instruction, 12(1), 311-326.

Syafril, S., \& Yaumas, N. E. (2017). The implementation of Tartil Method in improving elementary school students' ability in reading al-Qur'an. Khalifa Journal of Islamic Educational, 1(1), 1-14.

Weng, Y., Hsu, K. C., \& Liu, B. J. (2019). Increasing worldwide environmental consciousness and environmental policy adjustment. The Quarterly Review of Economics and Finance, 71, 205-210.

Winarno, B. (2014). Globalisasi dan rezim demokrasi poliarki: kebijakan integrasi ekonomi Indonesia. Jurnal Hubungan Internasional, 3(1), 1-12. 